\title{
Problems of aluminum foam soldering
}

\section{Problemy lutowania pian aluminiowych}

\section{Streszczenie}

Komórkowa struktura i wyjątkowe cechy pian aluminiowych są przyczyną problemów z ich lutowaniem. W artykule przedstawiono metody wytwarzania, strukturę, właściwości i zastosowanie pian aluminiowych. Scharakteryzowano również sposoby cięcia pian wodą, laserem i obróbką elektroerozyjną, jako metod przygotowania brzegów do lutowania oraz techniki łączenia pian: mechanicznych i spawalniczych ze szczególnym naciskiem na ich lutowanie miękkie i twarde. Określono ograniczenia i możliwości lutowania pian aluminiowych.

Słowa kluczowe: aluminium, piana metalowa, lutowanie

\section{Abstract}

The cellular structure and unique properties of aluminum foams cause problems with their cutting and bonding. This paper describes the production methods, structure, properties and application of aluminum foams. It also discusses foam cutting methods such as water jet, laser and electrical discharge machining as means of edge preparing for brazing and soldering. Among methods of foam mechanical and weld joining, particular focus is put on brazing and soldering techniques. The limitations and possibilities of aluminum foam brazing and soldering are characterised.

Key words: aluminum, bonding, metal foam

\section{Introduction}

Aluminum foams have been subject to extensive research due to their unique properties: low density, absorption of energy, vibration suppression, good thermal insulation. In his book [1] Grabian characterizes methods of manufacturing aluminum foams, summarized in Figure 1. These methods range from powder metallurgy, vacuum vaporization, through electrochemical deposition and foundry methods to the use of laser beam. Most common aluminum foams have a density ranging from $0.15-0.5 \mathrm{~g} / \mathrm{cm}^{3}$, with porosity reaching $75 \%$ to $95 \%$. Kathuria $\mathrm{Y}$. $P$. and others in the work [2] concentrate on aluminum foaming by $\mathrm{Nd}$-YAG laser beam, and describe a method of making a porous structure with relative density of $0.40 \mathrm{~g} / \mathrm{cm}^{3}$ and porosity $60 \%$. In places where a laser was used for foaming, the foam became broader. The structure and properties of aluminum foams depend on its density and on the open-to-closed pore ratio. Figure 2 illustrates the structure with the two types of pores, where cells are connected through nodes, from which struts extend, forming

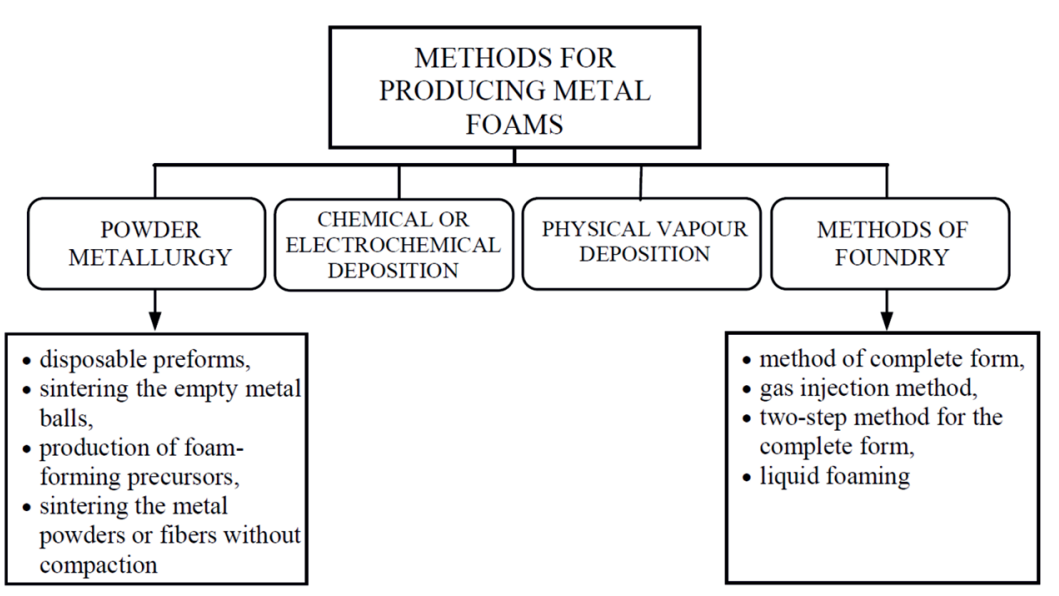

Rys. 1. Metody wytwarzania pian metalowych $[4 \div 6]$

Fig. 1. Methods for producing metal foams $[4 \div 6]$

Prof. dr hab. inż. Jerzy Nowacki, mgr inż. Sławomir Krajewski - Zachodniopomorski Uniwersytet Technologiczny w Szczecinie, prof. dr hab. inż. Janusz Grabian - Akademia Morska w Szczecinie. 
a)

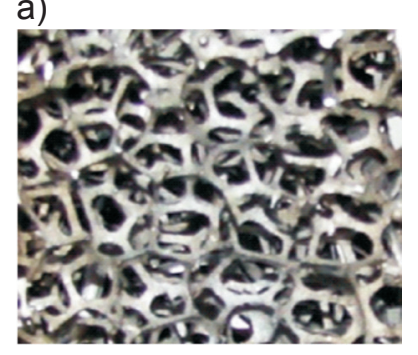

b)

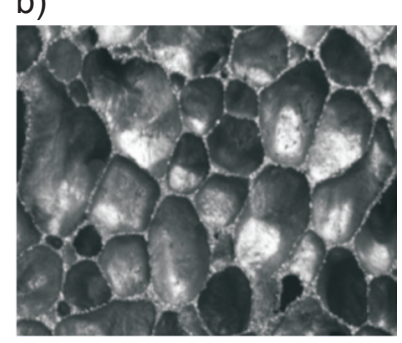

Rys. 2. Przykład struktury piany aluminiowej [1, 4]: a) pory otwarte, b) pory zamknięte

Fig. 2. Example of the aluminium foam structure [1, 4]: a) open pores, b) closed pores

a cell wall. The relative density of foam depends on the size and shape of cells, anisotropy and cell distribution in the material. Foam density is commonly measured by hydrostatic weighing of a sample, while geometric parameters are determined through macroscopic examination. Foams of higher density generally have pores of smaller diameters, more regular distribution, and there is greater probability that smaller pores will be located at nodes of large cells. As density decreases, smaller pores are absorbed by larger ones, that is why foaming is not uniform. Describing some foam properties, Malekjafarian M. and others [3] observe that higher density foams have higher mechanical properties, and that the denser the foam, the higher its ability to absorb energy, especially foams with closed cells. That is why foams are said to be multifunctional materials (Fig. 3) The cellular structure and unique properties of aluminum foams, however, cause problems when it comes to cutting and bonding.

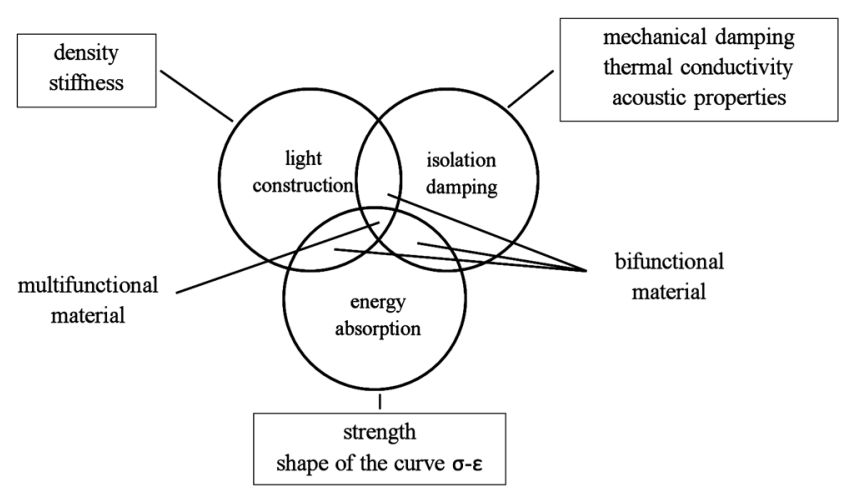

Rys. 3. Piany metalowe jako materiał wielofunkcyjny [7]

Fig. 3. Metal foams as a multifunctional material [7]

Practically, metal foams can be manufactured of any metal. The most common foams are made of pure aluminium, or magnesium, titanium, zinc, nickel, copper and iron or their alloys [1]. Properties of foamed metals make them an attractive structural material in the automobile industry, as well as in the production of machine tools, batteries, fuel cells, condensers or chemical equipment. The use of foams for car body plating is considered as an optional method for enhancing active safety of drivers and passengers. Aluminum foams have already found applications in the machine industry, mainly as vibration suppressors and noise absorbers, bumper components inserted in elastomer, in the chemical industry as heat exchangers, while combined with $\mathrm{SiC}$ are used in building fireproof bulkheads in ships. Abolghasemi Fakhri M. and others [8] indicate orthopedic and dental applications of titanium foam owing to its light weight, high strength, and full biocompatibility.

\section{Aluminum foam bonding}

Bonding techniques for aluminum foams include soldered, glued, and bolted joints, also those with inserts sunken in the foam (Fig. 4) Bolted joints of metal foams with acceptable strength are easy to make. The strength of bolted joints of metal foams depends on the type of bolt, diameter and depth of the hole, tightening torque, foam density and other properties.

Metal foam elements are joined together with standard glues used for joining non-porous materials. In case of metal foams, glued joint areas often turn out to be stronger than the foam itself. Disadvantages of glued joints include low thermal stability at high temperatures, different thermal expansion and different thermal and electrical conductivity than the foam itself, and susceptibility to ageing.

Welding aluminum foams is technologically difficult mainly because of varying pore size and non-uniform fusion of thin-walled skeletal structure.
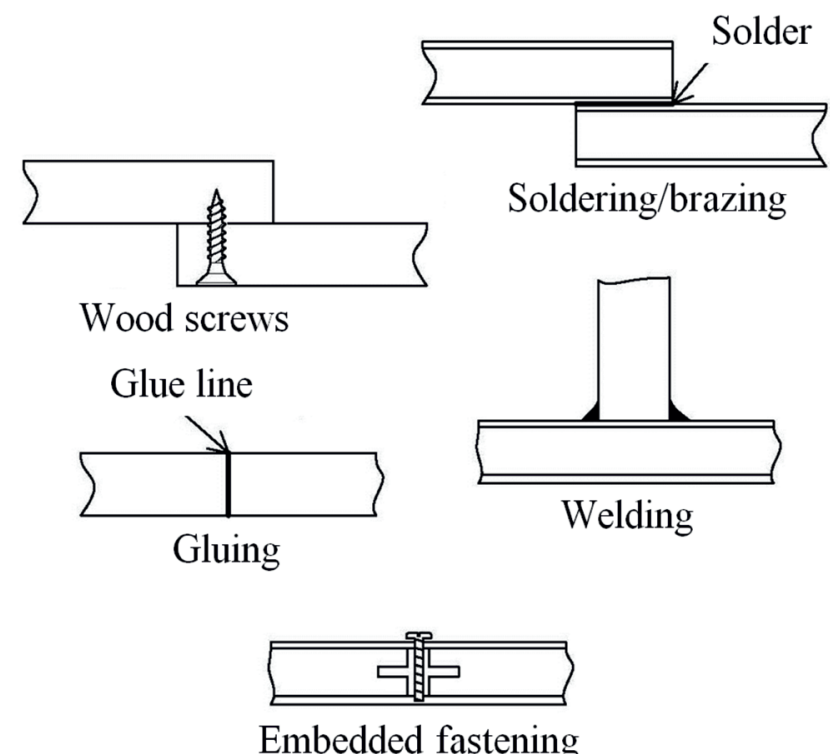

Rys. 4. Rodzaje złączy rozłącznych i nierozłącznych stosowanych do łączenia pian metalicznych [9]

Fig. 4. Types of separable joints and inseparable joints used to connect metal foams [9] 
Soldering aluminum foams also encounters technological obstacles, mainly because both filler metal and flux penetrate into the foam, and thin walls of the foam skeletal structure partially melt.

\section{Limitations in soldering aluminum foams}

Preparing foam edges for soldering requires that cutting products should be removed from its surfaces. It is difficult on porous structures due to irregular shape of pores and limited access to them. Contrary to mechanical cleaning, chemical treatment yields satisfactory results.

A varying size of soldering gap restricts uniform distribution of the solder and flux within the joint. The capillarity of the gap is much reduced or does not occur in the immediate vicinity of pores. In case of open pores, the flux penetrates into the foam, which means only a non-corrosive flux can be used. Foam porosity causes a substantial use of filler metal and flux as they escape deeper into the foam.

Another essential restriction in Al foam soldering is lack of methodologies of testing the geometry of edges prepared for soldering, or that for testing mechanical properties. Besides, criteria for soldered joint acceptance are not available.

Apart from problems resulting from foam structure, soldering aluminum is considered as a difficult process due to low melting point, high thermal conductivity and expansion, and a large shrinkage while aluminum cools down. A great affinity of aluminum for oxygen requires that aggressive fluxes be used to remove a layer of oxides $\mathrm{Al}_{2} \mathrm{O}_{3}$ from the specimen surface before soldering [10-13].

\section{Preparation of aluminum foam edges for soldering}

Methods for the preparation of non-porous edges of AISi9 alloys are well known and subject to relevant standards. Literature sources, however, hardly provide guidelines on techniques of preparing aluminum foam edges for soldering. Such preparation significantly differs from pre-soldering treatment of non-porous, or solid aluminum alloy edges. These problems result from the cellular structure of foams and their wall thickness, equal to or less than $0.3 \mathrm{~mm}$, while the voids are spaces where cutting products may gather. The presence of voids may critically destabilize the continuity of cutting process, particularly thermal cutting. The preparation of edges is difficult first of all because there are no criteria for the assessment of edge quality and limited possibilities of measuring geometric parameters. The choice of cutting method crucially impacts the edge quality.

Source information on the preparation of aluminum foam edges for soldering is scarce. Ashby M.F and others [9] recommend electrical discharge cutting allowing to maintain the structure continuity. Krajewski S. and Nowacki J. [14] have analyzed conditions of aluminum foam cutting and found that the best results are obtained by cutting with a beam of highly concentrated energy. Among the cutting methods that do not cause partial melting of a material, electrical discharge cutting offers the best results, then water jet with an abrasive. The edges after cutting have been examined as per PN-EN ISO 9013:2008 standards on Thermal cutting - Classification of thermal cuts - Geometric product specification and quality tolerances [15].

\section{Aluminum foam soldering tests}

We have performed soldering tests of silumin foams AISi9, cast by injecting gas into molten alloy. The soldered foam-foam and foam-non-porous material joints were of butt and tee type.

Filler metals used for testing the solderability of silumin foam are characterized in Table I.

Soldering was performed by using three sources of heat: propane-butane burner, hot air and heating in an electric furnace. Soft soldering was performed with the filler metal Castolin FCW198, and fluxes Castolin 157 and AluTin 51, characterized in Table II. For brazing with the filler metal AISi12 three fluxes were used: Castolin 192FX, InstalFlux TLA-4 and Castolin 190 (Table 2). The brazing solder B-ZnAl22, a rod with non-corrosive flux, has good wetting and flowing characteristics on joined surfaces. The observed partial melting of foam cell walls during soldering is due to a little difference between the melting points of the binder B-AISi12 and foam AISi9. The conditions and parameters of the soldering process were determined from many tests, separately for each filler metal and flux. We have assessed the soldering process, which included visual evaluation, macroscopic and microscopic metallographic examination of the joints. Problems occurring in flame soldering consisted in substantial plastic strains of thin cell walls due to heating. This phenomenon did not take place during hot air soldering, soft soldering in particular.

Soft soldering rods S-ZnAl4 FC and S-Zn80AI5SnAg FCW 198 from Castolin have shown medium and high flowing power and good wetting. Joints soldered with FCW 198 and ZnAl4FC are corrosion resistant and strong. These rods have a lower melting point compared to joined thin-walled porous materials, such as aluminum foams, consequently they cause less strain. Residues of fluxes based on chlorides and fluorides of alkali metals have to be removed from the joint area due to their strongly corrosive action. 
Tablica I. Spoiwa do lutowania aluminium

Table I. Filler metals for aluminum brazing

\begin{tabular}{|c|c|c|c|c|c|c|}
\hline Product & $\begin{array}{c}\text { Chemical } \\
\text { composition }\end{array}$ & Form & $\begin{array}{l}\text { Melting } \\
\text { temp. } \\
\text { range, }{ }^{\circ} \mathrm{C}\end{array}$ & $\begin{array}{c}\text { Temp. of } \\
\text { soldering } \\
{ }^{\circ} \mathrm{C}\end{array}$ & Soldering assessment & Solder characteristics \\
\hline $\begin{array}{l}\mathrm{ZnAl4} \\
\mathrm{FC}\end{array}$ & $\begin{array}{c}96 \% \mathrm{Zn}, \\
4 \% \mathrm{Al}\end{array}$ & $\begin{array}{l}\text { rods } \\
\text { with flux } \\
\text { coating }\end{array}$ & $385 \div 418$ & 410 & $\begin{array}{l}\text { combustible flux, while } \\
\text { burning it emits intense } \\
\text { smell resembling polymers; } \\
\text { hard to melt; medium } \\
\text { flowing power }\end{array}$ & $\begin{array}{l}\text { solder with flux coating, low melting } \\
\text { point; used for soldering thin-walled } \\
\text { components of aluminium }\end{array}$ \\
\hline ZnAl22 & $\begin{array}{l}78 \% \mathrm{Zn} \\
22 \% \mathrm{Al}\end{array}$ & $\begin{array}{l}\text { flux- } \\
\text { cored } \\
\text { wire }\end{array}$ & $426 \div 485$ & 485 & $\begin{array}{l}\text { low flowing power, good } \\
\text { wetting, rather easy to melt }\end{array}$ & $\begin{array}{l}\text { solder with flux core, guarantees } \\
\text { good mechanical properties and } \\
\text { corrosion resistance; for joining } \\
\text { aluminum and its alloys with copper } \\
\text { or stainless steel }\end{array}$ \\
\hline $\begin{array}{l}\text { Castolin } \\
\text { FCW198 }\end{array}$ & $\begin{array}{c}80 \% \mathrm{Zn} \\
5 \% \mathrm{Al} \\
\text { plus } \mathrm{Ag}, \mathrm{Sn}\end{array}$ & $\begin{array}{l}\text { wire } \\
\text { without } \\
\text { flux }\end{array}$ & $385 \div 418$ & 410 & $\begin{array}{l}\text { good wetting, high flowing } \\
\text { power }\end{array}$ & $\begin{array}{l}\text { soft solder for joining aluminum and } \\
\text { its alloys with copper; has good } \\
\text { corrosion resistance }\end{array}$ \\
\hline AISi12 & $\begin{array}{l}88 \% \mathrm{Al} \\
12 \% \mathrm{Si}\end{array}$ & $\begin{array}{l}\text { wire } \\
\text { without } \\
\text { flux }\end{array}$ & $575 \div 585$ & 610 & $\begin{array}{l}\text { medium flowing power, } \\
\text { medium wetting, hard to } \\
\text { melt }\end{array}$ & $\begin{array}{l}\text { hard solder for joining aluminum and } \\
\text { its alloys with copper or stainless } \\
\text { steel; good corrosion resistance }\end{array}$ \\
\hline
\end{tabular}

Tablica II. Topniki do lutowania aluminium Table II. Aluminum brazing fluxes

\begin{tabular}{|c|c|c|c|}
\hline Product & Form & $\begin{array}{l}\text { Active temp. } \\
{ }^{\circ} \mathrm{C}\end{array}$ & Flux characteristics \\
\hline Castolin 190 & powder & $500 \div 700$ & $\begin{array}{l}\text { flux Castolin 190, powder, recommended for use with solder alloy Castolin } \\
\text { 190; flux removes oxides from the joint surface, which enables capillary } \\
\text { action of molten solder, thus joints can be made in various required } \\
\text { positions; corrosive residues have to be removed after soldering; this flux } \\
\text { can be used for Al alloys containing up to } 1.5 \% \mathrm{Mg} \text {; corrosive }\end{array}$ \\
\hline Castolin 157 & liquid & $150 \div 450$ & $\begin{array}{l}\text { for soft soldering; Castolin } 157 \text { is an effective medium removing oxides } \\
\text { from various metal surfaces, which allows for wetting and flowing of the } \\
\text { molten solder in a joint, filling it tightly and providing for high strength }\end{array}$ \\
\hline AluTin 51 & gel & $120 \div 350$ & $\begin{array}{c}\text { for soft soldering; AluTin } 51 \mathrm{~L} \text { gel flux is designed for joining aluminum } \\
\text { with other metals. AluTin } 51 \text { alloy for soft soldering, designed for joining } \\
\text { aluminum with other metals }\end{array}$ \\
\hline $\begin{array}{l}\text { Castolin } \\
\text { 192FX }\end{array}$ & powder & $420 \div 470$ & $\begin{array}{l}\text { for joining aluminum and its alloys, copper and possibly } \mathrm{Cr} / \mathrm{Ni} \text { steel; } \\
\text { non-corrosive }\end{array}$ \\
\hline $\begin{array}{l}\text { INSTALFLUX } \\
\text { TLA-4 }\end{array}$ & paste & $420 \div 480$ & $\begin{array}{l}\text { non-hygroscopic flux for soft soldering of aluminum and its alloys with } \\
\text { Zn-Al filler metals. Flux residues are not corrosive }\end{array}$ \\
\hline
\end{tabular}

\section{Macro- and microstructure of soldered Al foam joints}

In macroscopic examination of the joints we have used a stereo microscope Nikon AZ100 with LED illumination. For inspection of the joints we have taken longitudinal and cross microsections, ultrasonically cleaned with acetone, and etched in $1 \%$ hydrofluoric acid. The microscopes used were an optical microscope Nikon AZ100 and SEM JOEL JSM-6100.
Macroscopic images reveal the propagation of the solder into the joined material and discontinuities formed through physical and chemical processes. In case of aluminum foams the difference between the soldered joint and porous material is clearly seen. Positive effects were achieved due to hot air soldering with the solder Castolin FCW198 flux 192FX.

Macro- and microstructures are shown in figures $6 \div 8$ 


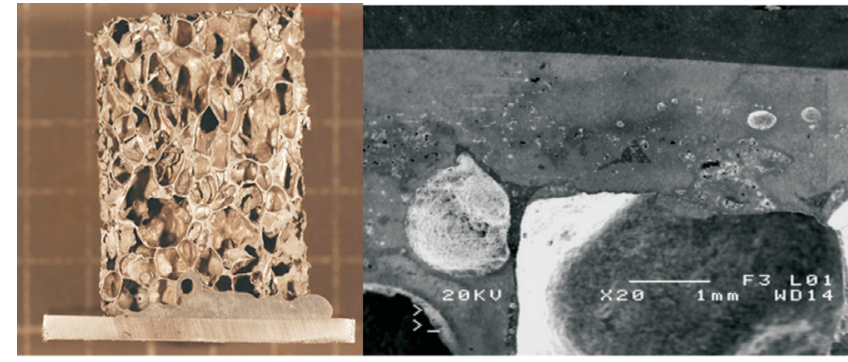

Rys. 5. Złącze piana-blacha Al, lut ZnAl22, obraz makro i mikroskopowy. Na obrazie mikroskopowym widoczne przetopienie i wymieszanie ścianek pianki z lutem oraz widoczny por niewypełniony przez ciekły lut Fig. 5. Al foam-Al sheet brazed joint, ZnAl22 brazing metal, macro- and micro- image. The microscopic image reveals melting and mixing of foam cell walls with filler metal and a visible pore not filled with liquid solder

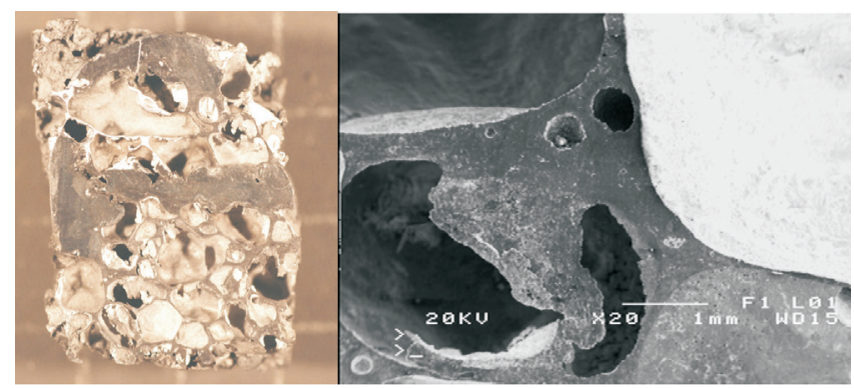

Rys. 6. Złącze lutowne piana - piana aluminiowa, lut ZnAl4, obraz makro i mikroskopowy. Na obrazie mikroskopowym widok niewypełnionego do końca pora w obszarze linii wtopienia, po prawej widoczny lut, a po lewej stronie widok lutu zakrzepłego w porze

Fig. 6. Al foam-Al foam brazed joint, ZnAl22 brazing metal, macroand micro-image. In the microscopic image: partially filled pore in the line of melting, solder visible on the right, solder solidified in a pore on the left

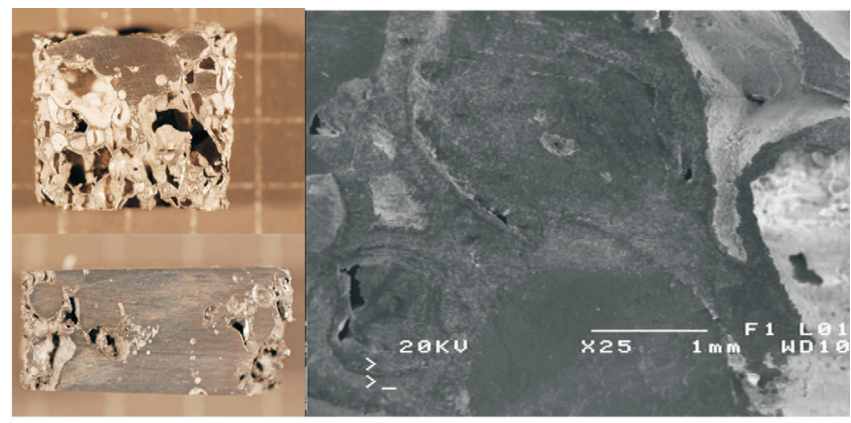

Rys. 7. Lutowana piana Al w płaszczyźnie wzdłuż złącza i w poprzekuwidoczniono propagację lutu w 2 kierunkach w porach piany aluminiowej, lut ZnAl4, obraz makro i mikroskopowy. Na obrazie mikroskopowym widok niezgodności powstałych przy ściankach komórek spowodowany średnią rzadkopłynnością lutu i średnią zwilżalnością

Fig. 7. Brazed Al foam cut lengthwise and crosswise of the joint, brazing metal propagation in two directions in the pores of the aluminum foam is visible, ZnAl4 brazing metal, macro- and micro-image. The microscopic image shows imperfections formed on cell walls due to medium flowing power and medium wetting of the brazing metal
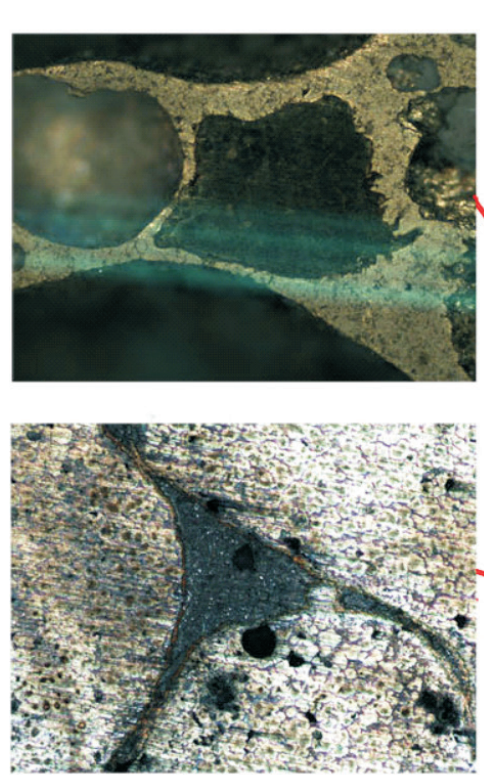

Rys. 8. Złącze lutowane piana-piana aluminiowa, lut Castolin FCW198, obraz skumulowany makro- i mikroskopowy

Fig. 8. Al foam-Al foam brazed joint, Castolin FCW198 brazing metal, integrated macro- and micro- image
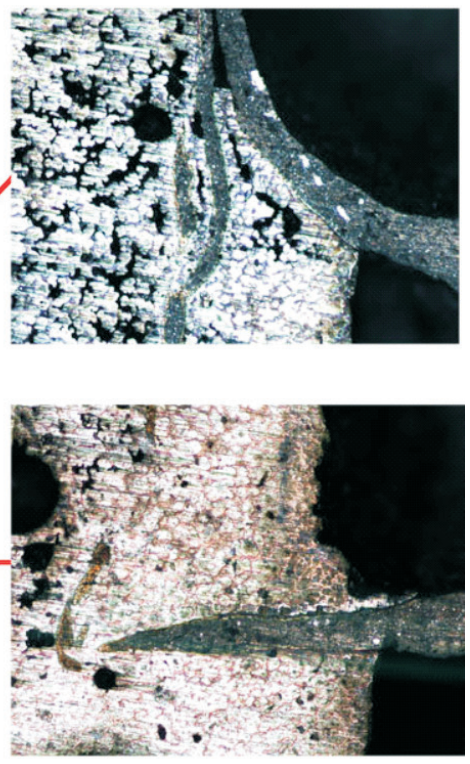


\section{Conclusions}

1) Aluminum foams can be soldered, but with the present state of the art such soldering faces a number of restrictions in technology and research.

2) Mechanical properties of aluminum foams do not justify the use of brazing.

3) The process of Al foam flame brazing, due to non-uniform heating of macro-areas of a specimen, causes non-uniform distribution of brazing metal in the pores and foam structure strain due to partial melting of cell walls. This phenomenon does not occur in hot air soldering.

4) Cognitive problems to be solved in the area of aluminum foam soldering are as follows:

a) influence of surface geometric parameters on elementary surface processes during soldering,

b) infiltration into pores and surface phenomena in pores, c) optimization of a soldering gap,

d) influence of pore infiltration with filler metal on joint properties,

e) deformation of foams during soldering,

f) influence of foam reinforcement on the process and effect of soldering,

g) quantitative metallographic analysis of joint area structure,

h) influence of the joint area structure on its mechanical and thermal properties,

i) numerical analyses of stress distribution, heat distribution during thermal shocks, and modeling of a joint area structure.

\section{Literature}

[1] Grabian J.: Metalowe piany kompozytowe w przemyśle okrętowym, Szczecin 2012

[2] Kathuria Y.P.: Nd-YAG laser assisted aluminum foaming, Journal of Materials Processing Technology Volume 142, Issue 2, 25 November 2003, s. 466-470.

[3] Malekjafarian M., Sadrnezhaad S.K.: Closed-cell Al alloy composite foams: Production and characterization, Materials and Design, 42 (2012) s. 8-12.

[4] http://tworzywa.com.pl/Wiadomo\%C5\%9Bci/Pianki-polistyrenowe-w-budownictwie-struktura-a-w\%C5\%82a\%C5\%9Bc iwo\%C5\%9Bci-21020.html.

[5] Smitek K.D.: Mietałły - Sprawocznik, Mietałłurgia, Moskwa 1980.

[6] Sobczak J.: Piany metalowe monolityczne i kompozytowe oraz gazary, Instytut Odlewnictwa, Kraków 1998.

[7] Banhart J.: Metallic foams II: Properties and Applications. http://materialsknowledge.org/docs/Banhart-talk2.pdf.

[8] Abolghasemi Fakhri M., Bordatchev E. V., Tutunea-Fatan O. R.: An image-based methodology to establish correlations between porosity and cutting force in micromilling of porous titanium foams, Int J Adv Manuf Technol, (2012) 60: s. 841-851.

[9] Ashby M.F.: Evans A.G., Fleck N.A., Gibson L.J., Hutchinson J.W., Wadley H.N.G.: Metal Foams: A Design Guide, Butterworth-Heinemann 2000.

\section{Acknowledgements}

This article has been written under the project NCBiR No PBS1/A5/6/2012 titled Composite metal foams - thermal treatment, cutting, joining.
[10] Grabian J.: Determination of metal foam flow conditions at a temperature higher than the liqidus temperature, Archives of Foundry Engineering, Vol. 11, 1/2011, s. 27-30.

[11] Hyun-Ho K., Soon-Bok L.: Effect of a brazing process on mechanical and fatigue behavior of alclad aluminum 3005 , Journal of Mechanical Science and Technology, 26 (7) (2012), s. 2111-2115.

[12] Weng W.P., Chuang T.H.: Interfacial Characteristics for Brazing of Aluminum Matrix Composites with Al-12Si Filler 28A, December 1997-2673

[13] Yiyou Tu, Zhen Tong, Jianqing Jiang: Effect of Microstructure on Diffusional Solidification of 4343/3005/4343 MultiLayer Aluminum Brazing Sheet, Metallurgical and Materials Transactions, A Volume 44A, April 2013-1761.

[14] Krajewski S., Nowacki J.: Preparation of aluminium foam edges for welding, Advances in Materials Science, Vol. 13, No. 3 (37), September 2013

[15] PN-EN ISO 9013:2008 Cięcie termiczne - Klasyfikacja cięcia termicznego - Specyfikacja geometrii wyrobu i tolerancje jakości. Metals, Metallurgical and Materials Transactions, A Volume 